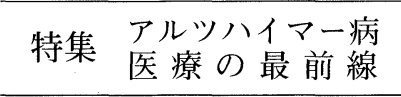

順天堂医学 $47(1)$

p. $23 \sim 35(2001)$

\title{
痴呆性疾患専門施設での対応と展望**
}

\section{Management and perspective for dementia care in the facilities}

\author{
高 野 喜久雄* \\ KIKUO TAKANO
}

\begin{abstract}
本稿ではアルッハイマー患者への対応に関してハード・ソフトの両面から，今後の方向性を含 め, 現状を解説していく.

まず環境の重要性を考察し，つぎに施設における全身管理という視点から，高齢の患者に大変 重要な栄養アセスメントの, 一方法として試みた体重測定について, その経緯を報告する. 行動 記録表の項では，高齢者への薬劑投与の効果や副作用を知る指針として，またスタッフが適切な 対応を図るための情報として，有効に活用されている『 24 時間行動記録表』を紹介する.

心の安心, くつろぎというソフト面からは, 本院で実施しているアクティビティプログラムと, そこに共通する基本理念について述べてみたい，さらにく思い出療法〉について，またそのため のく場〉としての思い出ミュージアムを紹介する.

キーワード：アルツハイマー, 環境, 体重測定, アクティビティ, 思い出療法
\end{abstract}

Key words : Alzheimer's disease, environment, body weight, activity, reminiscence

\section{はじめに}

アムステルダムから電車で 30 分のところにハー レムという所がある。ニューヨークにも同名の， あまり健全とはいえない街があるが, 地名として はこちらが《本家》である.

ここに『アントンペックホフ』という施設を訪 ねたことがある、今で言うグループホームをいく つか束ねたような形のものである.

ケア，特に痴呆の患者にとっての住環境は，

*医療法人誠馨会総泉病院院長

Sohsen Hospital, Chiba, Japan.

* 順天堂大学医学部非常勤講師 (膠原病内科学)

Department of Internal Medicine and Rheumatology, Juntendo University School of Medicine, Tokyo, Japan **第294 回順天堂医学会学術集会 [Nov. 18, 2000 開催〕 [May 29, 2001 原稿受領]
少人数の単位からなるユニットがよいというのが 最近の傾向で, わが国でもグループホームが多数 つくられるようになっているが，ここはその先例 ともいえる.

少人数の住まい（ユニット）が $6 つ$, 中庭を囲 んでいる１ユニットには6つの個室と，皆で過 ごすリビングルーム，一緒に使う台所，そして共 同の浴室とゲスト用の部屋がある.

ここで, 痴呆の高齢者が料理をしている姿を初 めて見た。もう 10 年近く前のことである.ナイ フを手に，夕飯の支度をしているので，思わず 「㭌を扱っても大丈夫か？」とたずねると，ケー スワーカーは「何の心配もない」と答え，むしろ 「なんでそんな当たり前のことを聞くのか？」と いう表情であった。

このことは 4 年後, 私の働く病院のアクティビ ティにも取り入れられた。痴呆であっても, 料理 
を始めると以前のようなく主婦〉の顔を取り戻す のである。むろん中には危険な人もいるので， 個々の状態をよく把握した上で行う必要はある。 しかし「家にいるように過ごす」ことが，痴呆の 患者には大きな意味があるということが，実感さ れる事例であった，女性から買い物と料理の機会 を奪うと，呆けていくようである.

さらに〈環境全体によるケア〉という視点を持 つ上で参考になったのは，イギリスのスターリン グ大学で耳にした《snoezlen=スヌーズレン》 という言葉である。

日本ではさほど一般的になっていないようだ が, この言葉はオランダ語の「スヌッフレン ( く んくん嗅ぐ)」と「ドゥーズレン（うとうとする， リラックスする)」からの合成語である，受け入 れやすい，くつろげる環境の中で，快適さを味わ い楽しむというもので，そのための空間自体を示 す場合もある。

香りは記憶を喚起する引き金ともなるが，ス ヌーズレンはその語源からイメージできるよう に, 匂いを含め, 光・音・感触など五感のすべて に働きかけるものである.

心地よい刺激に，思わずうとうとと眠気をさそ われるような快適さは，まさに子供の頃の午後の まどろみのようなく寛ぎ〉といえる。

痴呆患者には多面的な配慮とさまざまな対応が 必要である、建物設計といったハード面から活動 プログラムなどのソフトまで，さまざまな視点か ら，いくつかの例を紹介する.

\section{痴呆と環境}

身体と認知力の両方の障害をもつ痴呆症の患者 にとって，環境の与える影響は大きい，小さな変 化にも敏感に対応して改善が見られる例があり， またその逆もある。

物理的な環境の整備が痴呆の治療に効果をあげ ることは, ミシガン大学のプロジェクトにおいて 報告され，また多くの研究によって，理論的にも 裏付けられている.

\section{1. 施設について}

施設とは，よく配慮されたものであっても，家 庭とは全く異なる規模やシステムで運営されるも のである。したがって痴呆患者の住む環境として 最善とはいいがたい.

〈施設〉の特徵を, Kruzichは以下のようにま とめている.

1）日常生活に余裕がない

2 ) スタッフと居住者の間に社会的距離がある

3 ) ケアが必ずしも個々に適合していない

4 ) プライバシーへの配慮が欠如している

5 ) 同じ時間に大勢が同じことをするなど，主 体性を妨げたり，活動を無理強いするよう なスケジュールが組まれる

こうしたことは，わが国の施設に打いても，し ばしばみられるように思われる。

2. 自宅のような感覚へ

Weismanは, 痴呆症の患者に必要なのは，身 体障害者のために開発されたもののような，費用 のかかる装置や，技術的な看護ではないとしてい る。痴呆を改善するのは，自宅で暮らすような䨌 囲気であるという。このく自宅感覚〉とは，単に 家具や工芸品の問題ではない。一人ひとりに個性 的な環境を与え，それをコントロールできる機会 を与えることや，他の人との接触とプライバシー を，望む時に選択できることなどにより作りださ れるものであるという。

Weismanはまた, (1)患者, (2)治療目標，そして 3 つの治療環境 ( (3)物理的環境, (4)運営的要素, (5)社会的要素 ) という5つの要素の相関について 述べているので, その概念困を示しておく(罒-1). 痴呆の治療環境に含まれる運営的・物理的・社 会的の3つの要素は, 〈治療目標〉によって内容が 明確となる. また目標の実現に貢献するとともに， 患者によい影響を与えることができる，運営的要 素とは施設の目的や方針であり,社会的要素とは, 家族・友人また施設の同居者との関係などのこと である. 物理的環境とは室内構成, 個々の部屋や 活動場所の配置などを含む。

こうした概念により構築される環境の基本にあ 


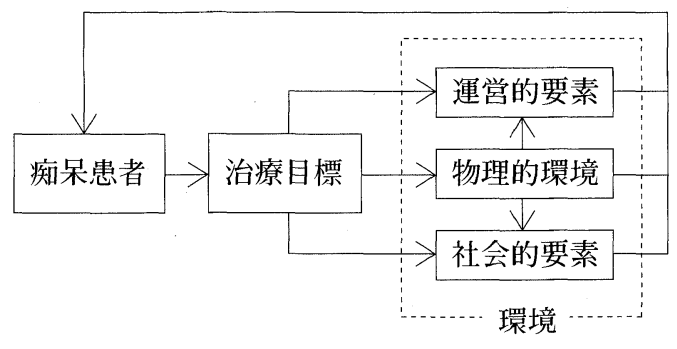

図-1 Weismanの概念図

るテーマは，家庭的で非収容施設的ということで ある.つまり「家庭的なもの (雲囲気・機能など) を保持し続けること」が, 施設の究極の目標であ るというのがWeismanの説である.

彼は建築デザインや運営方針, プログラムなど の見地から9つの治療目標をあげ，これにより痴 呆症の人達と環境との望ましい関係が明確になる と論じている.

3.9つの治療目標について

1 ) 安全と保安の確保

身体能力と認知力の両方が障害された痴呆患者 は, 環境への対応が困難で, さまざまな面から傷 つけられることが多い.

2 ）有意義な余暇活動による機能的能力の支援 ゆきすぎた傷害視を改め, 有意義な余暇活動の 中で通常の生活行動をしたり，役割を果たす機会 を与えることにより，機能的能力の維持あるいは 向上も可能である。

3 ) 環境の認知力と方向感覚の強化

今いる場所，時間などへの認識 (見当識) をサ ポートすることにより, 痴呆患者の混乱と不安を 除き，徘徊を予防することができる。

4 ）調節された刺激とチャレンジの機会の提供

強い刺激は痴呆患者にとって重荷となるが, 刺 激を避け過ぎても痴呆は改善せず，症状が悪化す ることがある。「ストレスにならない程度の刺激」 と「達成可能な目標に自発的に取り組める機会」 を与えることが大切である。

5 ）自立と自制の最大強化

施設においてよく見られる「習得された依存
性」をなくし，自分の人生を自分で決定し，責任 をもてるよう, 彼ら自身の環境に関して,できる限 り自分で決定できるよう推奨されるべきである.

6 ) 変化するニーズへの対応

痴呆患者は, 短期間でもさまざまな変化を示し， その状態も個人差が大きい。こうした変化に対応 していくことは重要である.

7 ) 社会的関係をもつ場や機会の提供

社会的接触は，重要な治療活動である。イスの 配置といったちょっとした工夫でも効果を上げる ことができる。

8 ) プライバシーの必要と保護

友人や家族と過ごすことができる場と併せて， 患者が望んだ場合は一人になることが可能な空間 も必要である。痴呆患者は公的なものから私的な ものまで, 多様な活動や空間を体験すべきである.

4.ケアと環境に打ける基本ともいえる 200 ゴールについて

Hiattは，患者の環境として患者自身・職員・ 施設と運営の 3 項目に大別した 20 のゴールという のを設定している. Weismanの説との重複もあ るが，切り口が違うので，ここに併せて紹介して おく.

ふ患者自身の能力に関するゴール

(1)集中力を最大にのばす

(2)安心感・快適さを増大させ, 感情のバランス を保つ

(3)不安・葛藤・怒り (興奮) を軽減させる

(4)矛盾への対応

(5)身だしなみ（トイレ・洗面・着替えなど）の 継続

(6)個人に合わせたペース・時間どおりに機能さ せる

(7)プログラムやサービスを通じて，記憶力低下 に対する不必要な不安・苦悩を予防する

8患者の個人的な宗教への崇拝のアクセスを供 給する

そスタッフの教育に関するゴール

9)患者が無力なことを理解し，応じる

10発語を促し，普通の交流を心掛ける 
(11)集団として扱うのでなく，個人個人と交流する (12)身体的抑制や薬による抑制を極力控える

(13)一つの介護法だけをすべての患者にあてはめ

ることなく，プログラムを絶えず検討し，常 によりよいものを目指していく.

々施設の設備・運営に関するゴール

(14)日常生活 (食事・入浴・身だしなみ等) の自 立を最大限に可能にする

(15)新鮮な空気・運動・気分転換のための自然環境 (16)患者の過去・家族との思い出・情緒的なもの と結び付くような環境づくり

(17)視覚・聴覚・触覚・嗅覚などの低下を補う

（代償する）ものを用意する

(18)ケアの単位を, $2 \sim 3$ 人から $5 \sim 6$ 人といっ

た，目の届く範囲の人数に止める

(19)イライラさせる不快要因をとりのぞく

20たずねてきた家族や友人と，楽しく過ごせる 場所を提供する

5. 俳徊への対応としての〈回廊〉について

徘䧃という言葉はとどまることのない感をもた せる，徘徊する患者は行き止まりがあるとフラス トレーションを起こすので, 歩き続けられるよう な形にすればよいとの考えもあり，回廊という方 式が採用されるようになったのであろう。しかし 現在では，この考え方は再検討されている.

徘徊にはさまざまな要因があるが, 次のような 区分で考えてみる必要がある.

(1)痴呆の患者のブラブラ散歩レベル

(2)施設内の閉鎖感がいやなための歩行

(3)自分がどこにいるか, わからないためのさま よい歩き

実際には，痴呆患者が全員徘䧃するわけではな く，また徘徊の程度にも差がある。一概に， [痴呆 $] \rightarrow[$ 問題行動 $] \rightarrow[$ 徘徊 $]$ というパターン で括ってしまう見方には問題があうう。

連続性を回廊に求めず, [家 $] \Rightarrow[$ 庭 $] \Rightarrow[$ わか りやすい道］ $\Rightarrow[$ 家 $]$ という動線に導くような作 りになっているグループホームを, オーストラリ アに見た．ランドマークをつくることに加え， 道・場所を認識しやすくする方法なども考えるべ
きであろう．散歩道には足を休めるイスやべンチ を置くと, 安心感をもたらす効果がある.

6. カラーリングについて

海外ではたいへんカラフルな施設も視察した。 エリアごとに色分けされ, 部屋の前や曲がり角に は特定の色を使用, ドアにも原色が使われていた。 これは自分の居場所の把握を助ける手掛かりとし ての働きだけでなく, 色彩による刺激といった メリットも考えられる.

〈住まい〉らしい落ち着きのある内装と, わかり やすい鮮やかなカラーリングとの両立は, 今後検 討されるテーマかと思われる.

例えばパステルカラーは心の落ち着きを感じさ せる色彩犬゙が，視力の衰えた高齢者にとって， 認識しやすさ, 印象深さという点ではやや問題が ある.

7. ユニットケアについて

「家庭のような」環境に近づけるため, 特に痴呆 の患者のケアは, 少人数の単位からなるユニット がよいとされるようになってきた。

大規模な施設では，9人程度をひとつのケア単 位として対応しているところがある。グループ ホームも最近各地に作られ，よい成果を上げてい る所も多いが, 経営的な面からはいまひとつの感 がある. 熱意は大事だが, 安定経営ということも 今後のグループホームの課題といえよう。ユニッ トの人数が少ないほど, スタッフは患者の特性を よく把握できる。さらに患者も社交性が増し, 患 者同士,あるいは職員に親近感をもつようになる。 施設の方向性として, 少人数のユニット方式は, 今後増加してほしいシステムである。

\section{栄養モニタリング}

\section{1. 栄養アセスメント}

高齢になると，栄養摂取にさまざまな障害がみ られるようになる，摂食障害・㫶下障害などによ る困難のほか, 摂取量そのものが知らずしらずの うちに低下して，低栄養になる例も少なくない． 本院で行っている栄養アセスメントについて述べ 
たい．当院では全身状態のアセスメントを目的と してく全身プロファイリング〉という検査セット を行っている。

血算・生化学検査として，へモグロビン・コレス テロール・アルブミン・血液尿素窒素 $(\mathrm{BUN}) \cdot$ $\mathrm{Na} \cdot \mathrm{Cl} \cdot \mathrm{K} \cdot$ 乳酸脱水酵素 $(\mathrm{LDH})$ のセット検 査である.

栄養状態は，このうちへモグロビン・アルブミ ン・コレステロールを測定することにより，かな りの評価ができるかと思う。プレアルブミン・ト ランスフェリン等の測定も有効だが，日常の検査 としてはなじみにくく検査料金も高い. 少ない検 査で効果的に情報を得るコストパフォーマンスの 高い検查方法の検討が, DRG／PPS時代にあっ ては今後ますます必要になろう。

2. 体重の変化と全身状態

高齢者の全身状態をモニタリングする超簡易ア セスメントとして，体重測定が役立つ。痴呆病棟 に入院中の 18 人について，入院後 $6 \sim 12$ 力月の 体重変化を記録したところ, [上昇傾向 8 人］［下 降傾向 5 人，残る 5 人には [下降後の安定，また は上昇が見られた。この測定結果に，アルブミ ン, コレステロールの数值をあわせてみると, 両 者と体重の変化は概ねパラレルに変化しているこ とが認められる（図-2）。

こうした結果から，体重測定は極めて簡便に
計測できるものでありながら，患者の状態把握に は有用なデータであるということがいえる。ただ し必ずしもパラレルな変化が見られない場合もあ るので, 体脂肪測定の結果も併せて検討すること により,さらにキメ細かなチェックが可能となろう。

3. 痴呆と掑食の関係について

痴呆患者に扎いては, MMSEによる痴呆の度 合いと体重の減少に相関がみられるとの報告があ り，側頭葉の萎縮が食行動に影響を与えるという 報告もある、環境からくるストレスなど社会的な 要因も，撕食に与える影響は大きい。体重減少や 低栄養は, 痴呆が原因で食事に困難が生じた結果, 掑取量が減少することに起因すると思われる.

痴朵が原因で食事に困難をきたす事態には, 以 下のような原因があげられる。

(1)食事の方法 (手順) がわからない

(2)食事の時間や場所がわからない

(3)食物であることが認識できない

(4)空腹を自覚できない

(5)食事していることを忘れる

(6)食事動作がコントロールできない

痴呆患者の行動は極めて個別性が高く, 類型に よる明確な分類は困難である. 食事における障害 も，個々にその場で対処されていくことが多い. しかし食行動のパターンをある程度分類して, 求 められる介護の質を推察し，より適した対応を図

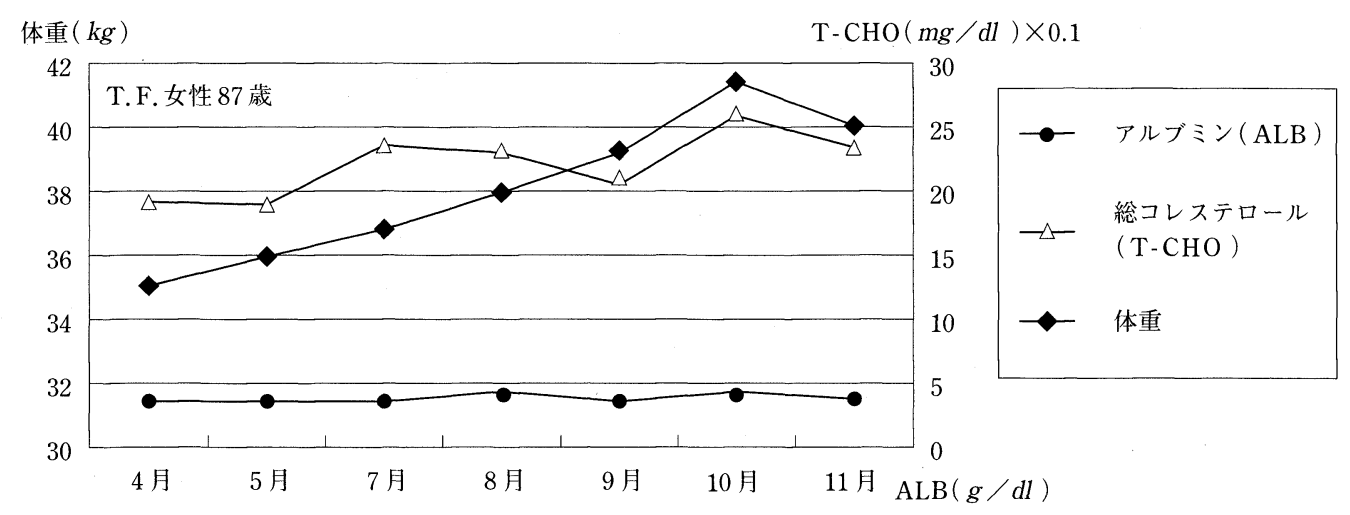

図-2 体重・アルブミン・総コレステロールの関係 
ることで, 問題の改善や解決につなげようとする 試みもある。以下に紹介する《Blandford scale》 がその例である。

4.〈Blandford scale〉( 食行動の障害)

1 ) 抵抗的態度 (防衛のための反応)

(1)首を振ってスプーンをよける

(2)食べ物が入らぬよう手で口をふさぐ

(3)食物や介護者を遠ざけようとする

(4)咬む・たたくなど介護者に乱暴する

(5)食べ物を放り出す

2 ）一般的な動作障害／失行・失認

（全体的な認識の欠如・混乱・注意力の散漫）

(1)ほめる・促す・励ますなど声による援助 がある時だけ自分で食べる

(2)箸やフォークを使わず手で食べる

(3)食事の道具 (箸など) が使えない

(4)食べずに，混ぜたりこねたりして遊ぶ

(5)喋ったり声を出し続けて, 食事をしない

(6)食物でない物を食べる

(7)食事中にテーブルを離れ，うろうろする

8)食べ物に気づかない，食べ物が認識でき ない

3 ) 選り好み (食事内容の変更の要求)

(1)特別な献立か, または別の料理の追加を 求める，あるいは食べない

(2)別の食物を求めるが, 少し食べると不満 を言い，あとは食べない

(3)一つの食物だけを食べ続ける

(4)いろいろな種類の物があっても（すすめ ても）食べようとしない

(5)少量食べただけで中断してしまうか，ま たは途中からは食べさせてもらう

（6流動食を好む（食事の半分以上）

(7)流動食のみを受け入れる

4 ) 口腔・咽喉部の嚥下障害

（食べさせてもらう時に，うまく口の動きを コントロールできない）

(1)言葉でなく，スプーンを唇に触れさせる など物理的な方法で促さないと，口を開 かない
(2)食物を近づけると，唇をすぼめる

(3)口を固く閉じたり，㐘を食いしばってし まうため，食物を口に入れられない

(4)絶えず舌や口が動いているため, 食物を 口に入れることができない

(5)一度は口に入れることができるが，吐き 出してしまう

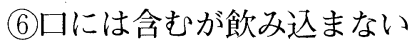

(7)食物があっても口を閉じないため，こぼ してしまう

5 ) 喉頭・食道部の燕下障害

（食物が気道にはいってしまう）

(1)むせる・咳き込む

(2)喉がゼイゼイ・ゴロゴロと鳴る

(3)声が㖽れる

6 ) 依存性

(1)少なくとも一度は問題行動がみられるが, 基本的には自分で食べることができる

(2)食事中に時々介助する必要がある。また は，日によっては介助が必要な時がある

(3)食べさせてもらう時だけ食べる

痴呆患者の食行動は，一般の高齢者の食行動と は異なる部分が多い。全身状態の管理と適切な ケアのためにも, このようなアセスメントは必要 であうう。

\section{4 時間行動記録表}

高齢者への向精神薬の投与に特に慎重を要する ことは論をまたない，本院では，薬㓮が適切に使 用されているか，またその効果を判定するための 指針として『行動記録表』が有効に利用されてい るので，その事例を報告したい.

1. 2 種の記録表

痴呆のある高齢者には, 他の患者との関係も含 めて問題行動がしばしば見られる。こうした対応 困難の患者に対しては，抗精神薬を使用する場合 が少なくない. 本院では, 効果の判定と経過観察 のため, 24 時間行動記録表を導入している. 
〈対象患者〉

記録の対象となる患者は, 次のような条件に合 致する者である。

1 ）新規入院患者で, 問題行動があるため抗精 神薬を投与しているが, 本人の入院以前の 状態が明確でないため, 観察の必要がある.

2 ) 在院の患者に問題行動が出現し, 向精神薬 投与を開始したため, 経過観察の必要が ある。

参考に，当院にて使用している記録用紙のサン プルを 2 種類示す.

『行動記録表』は1日を「午前 · 午後・夜間」の 3 つの時間帯に分け, 全体的な状態を 5 段階に評 価，さらに観察者が簡単なコメントを記入できる ようになっている.これにより数日間の変化を総
括的に把握することができる（図-3）.

一方『行動観察記録』は日内の変化をさらに 詳細に知るためのものである.1時間ごとに記入 し，1ページに 24 時間の記録が残せる。この表に は薬品の投与時間を記載するほか, 紙面下部には 使用している薬品名を明記する闌がある。コメン 卜欄には問題行動や向精神薬の副作用を記入する. 『行動観察記録』においては，精神面と行動 ( ADL ) の2つの視点からの記録も記入される. 精神評価は，ADL評価は○で，5段階評価の該 当箇所に印をつけることになっている（困-4). 5 段階評価は，個人による判断のバラつきを防止 するため，手順書が作成され，精神評価・ADL それぞれの5段階は，以下のような目安により設 定されている（表-1, -2）.

平成 12 年 6 月 24 日

患者名

\begin{tabular}{|c|c|c|}
\hline $9: 00$ & ベット上でTVをみている & ○山 \\
\hline $10: 00$ & Family面会中 & \\
\hline $11: 00$ & 放尿トイレ内にあり，ほう布, ズボン等, ぬれておりきがえする & \\
\hline $12: 00$ & 昼食摂取後, すぐ自室に戻る & \\
\hline $13: 00$ & $13: 30$ 放尿 & \\
\hline $14: 00$ & 家族の人と一緒に過ごす & \\
\hline $15: 00$ & ベット上で過ごす & \\
\hline $16: 00$ & 放尿 $\mathrm{W} / \mathrm{C}$ 乗車し，DルームでTVをみる & \\
\hline $17: 00$ & $\mathrm{~W} / \mathrm{C}$ 乗車中 & \\
\hline $18: 00$ & TVカードがなくなったから, 買いにいく. 売店が休みだからといっても納得せず & $\downarrow$ \\
\hline $19: 00$ & $\begin{array}{l}\text { 自室にもどり放尿発見. 下着に便がついていて着がえ介助するが, 手を便器にて洗う. } \\
\text { ベットにもどし寝るよう促す }\end{array}$ & 佐 $\bigcirc$ \\
\hline $20: 00$ & 声かけにスムーズに返答あり & \\
\hline $21: 00$ & 入眠中も病衣，下着のみ半分脱いでいる & \\
\hline $22: 00$ & 入眠中 & \\
\hline $23: 00$ & " & \\
\hline $24: 00$ & オムツ使用中ぬれているためオムツ交換しようとすると, オムツ交換するなとどなる & \\
\hline $1: 00$ & 入眠中 & \\
\hline $2: 00$ & " & \\
\hline $3: 00$ & " & \\
\hline $4: 00$ & " & \\
\hline $5: 00$ & オムツ交換後不穏となる.しばらくののち落ちつく & \\
\hline $6: 00$ & TVをみている & \\
\hline $7: 00$ & 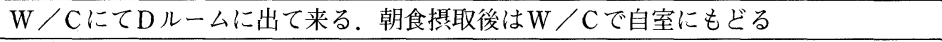 & \\
\hline $8: 00$ & 独歩にてDルームまで来て，トイレのさいそくあり．トイレ介助で排尿あり & $\downarrow$ \\
\hline
\end{tabular}

図-3 行動記録表 


\section{2. 行動記録の有効性}

1 ) 薬品の有効性の判断と日常の対応のため 行動記録表は, 薬品の投与開始から定常状態に なるまでの期間 ( $3 \sim 5$ 日) を配慮し, 通常は7 日 以上記録することになっている。その経過を見な がら, 薬品の増減あるいは継続，中断などを検討 していく.

この際一方的な見方に陥ることのないよう，各 部門の担当者によるカンファレンスを行いながら 判断していくようにしている.

前揭の行動記録表は70代男性のものである。
この患者には入院当初から軽度の問題行動が見ら れたが，配偶者の死亡をきっかけに問題行動が急 激に悪化した例である。

『行動観察記録』の積み重ねにより, 問題行動を誘 発する〈きっかけ〉が読み取れるようになるなど， 病棟での対応に有効に反映させることができた。

2 ) 服薬指導のデータとして

行動記録は，外来に打ける服薬指導の際に有用 である。日々状態の変わる痴呆の患者に対して適 正な投薬を行うためには, 日常の観察データが 不可欠となる。こうした判断材料としても，この

平成 12 年 7 月 24 日

\begin{tabular}{|c|c|c|c|c|}
\hline 時間 & 精神 / ADL評価 & 薬量 & 観察事項 & サイン \\
\hline $9: 00$ & $1 \cdot 2 \cdot 3 \cdot(4) \cdot 5$ & & 自宅へ帰るといって落ち着きなく動き回っている & ○倉 \\
\hline $10: 00$ & $1 \cdot 2 \cdot(3) \cdot 4 \cdot 5$ & & “Drと話しをさせろ”と訴え受付より病状を説明され少し納得された様子 & \\
\hline $11: 00$ & $1 \cdot 2 \cdot 3 \cdot(4) \cdot 5$ & & 車椅子を押してNSステーションへ来る. 再び落ちつかない様子で動いている & \\
\hline $12: 00$ & $1 \cdot 2 \cdot(3) \cdot 4 \cdot 5$ & & 昼食全量摂取する．薬内服していないと内服しているにもかかわらず何度も訴える & \\
\hline $13: 00$ & $1 \cdot 2 \cdot 3 \cdot(4) \cdot 5$ & (ia $0.375 \mathrm{mg}$ & Drよりの説明を全て忘れている. 家へ帰ると再びイライラしている様子 & \\
\hline $14: 00$ & $4 \cdot 2 \cdot 3 \cdot(4) \cdot 5$ & & $\begin{array}{l}13 “ 30^{\prime} \text { セレネース1 } 12 \text { 錠，臨時投与する } \\
\text { エレベーター前に行き“帰る”“家の者を呼ベ”等の訴え多い }\end{array}$ & \\
\hline $15: 00$ & $4 \cdot 2 \cdot 3 \cdot(4) \cdot 5$ & & $\begin{array}{l}\text { エレベーター前に車椅子に座っている. エレベーターが開くとすぐに乗り込む } \\
\text { NSが止めると殴りかかり車椅子をNSにぶつけようとする }\end{array}$ & \\
\hline $16: 00$ & $1 \cdot 2 \cdot 3 \cdot(4) \cdot 5$ & & $\begin{array}{l}\text { エレベーター前から離れず, 再びエレベーター開き乗り込む } \\
\text { 再び暴力行為あり. 家へ帰るとの訴えが強い }\end{array}$ & \\
\hline $17: 00$ & $1 \cdot 2 \cdot 3 \cdot(4) \cdot 5$ & & エレベーター前より離れず，車椅子に座っている & \\
\hline $18: 00$ & $1 \cdot 2 \cdot 3 \cdot(4) \cdot 5$ & 园 $0.375 \mathrm{mg}$ & 夕食椇取後自室へ戻りTVを見ている & $\downarrow$ \\
\hline $19: 00$ & $1 \cdot 2 \cdot(3) \cdot 4 \cdot 5$ & & & 植 $\bigcirc$ \\
\hline $20: 00$ & $1 \cdot 2 \cdot 3 \cdot 4 \cdot 5$ & & 入眠されている & \\
\hline $21: 00$ & $1 \cdot 2 \cdot 3 \cdot 4 \cdot 5$ & & " & \\
\hline $22: 00$ & $1 \cdot 2 \cdot 3 \cdot 4 \cdot 5$ & & $"$ & \\
\hline $23: 00$ & $1 \cdot 2 \cdot 3 \cdot 4 \cdot 5$ & & " & \\
\hline $0: 00$ & $1 \cdot 2 \cdot 3 \cdot 4 \cdot 5$ & & " & \\
\hline $1: 00$ & $1 \cdot 2 \cdot 3 \cdot 4 \cdot 5$ & & " & \\
\hline $2: 00$ & $1 \cdot 2 \cdot 3 \cdot 4 \cdot 5$ & & " & \\
\hline $3: 00$ & $1 \cdot 2 \cdot 3 \cdot 4 \cdot 5$ & & " & \\
\hline $4: 00$ & $1 \cdot 2 \cdot 3 \cdot 4 \cdot 5$ & & " & \\
\hline $5: 00$ & $1 \cdot 2 \cdot 3 \cdot 4 \cdot 5$ & & $"$ & \\
\hline $6: 00$ & $1 \cdot 2 \cdot 3 \cdot 4 \cdot 5$ & & 覚醒するも訴えなし & \\
\hline $7: 00$ & $1 \cdot 2 \cdot(3) \cdot 4 \cdot 5$ & & & \\
\hline $8: 00$ & $1 \cdot 2 \cdot(3) \cdot 4 \cdot 5$ & $0.375 \mathrm{mg}$ & 家へ帰るといって病衣を枕カバーにつめている & $\downarrow$ \\
\hline
\end{tabular}

精神評価 ( $)$ ADL評価 $(\bigcirc)$

$1=$ 悪い $2=$ やや悪い $3=$ 普通 $4=$ やや良い $5=$ 良い

向精神薬名 セレネース

図-4 行動観察記録の実例 
記録方法は有効である。

3 ）在宅患者の記録として

『行動記録表』については在宅の患者に配布す ることもある。次に来院するまでの家庭における 行動を記録してもらう。これにより，投与した薬

表-1 精神評価

（棓印を記入）

\begin{tabular}{|c|l|}
\hline 1. 悪い & $\begin{array}{l}\text { 他者とのトラブルが多い. } \\
\text { 表情·行動に落ち着きがない. }\end{array}$ \\
\hline 2. やや悪い & $\begin{array}{l}\text { 他者とのトラブルは少ないが, 表情・行 } \\
\text { 動に落ち着きがない. }\end{array}$ \\
\hline 3. 普通 & $\begin{array}{l}\text { 他者とのトラブルは少なく, マイペース } \\
\text { で行動する. }\end{array}$ \\
\hline 4. やや良い & $\begin{array}{l}\text { 他者とのトラブルはなく, 行動は落ち着 } \\
\text { 小ている. 指示にも対応できる. }\end{array}$ \\
\hline 5. 良い & $\begin{array}{l}\text { 他者と穏やかに関わることができる. 指 } \\
\text { 示にもスムーズに刘応できる. }\end{array}$ \\
\hline
\end{tabular}

表-2 ADL評価

（○即を記入）

\begin{tabular}{|c|c|}
\hline 1. 悪い & $\begin{array}{l}\text { 常にもうろうとしている. 声掛けに反応 } \\
\text { が鈍い. 体動が少なく，自力で食事が } \\
\text { できない. 掑食障害がある. 発語がない. } \\
\text { 歩行時にふらつさ強い. }\end{array}$ \\
\hline 2. やや悪い & $\begin{array}{l}\text { 居眠りが多い．声掛けに反応はあるが， } \\
\text { 行動が遅い．自力で食事できていた人が， } \\
\text { 誘導しないとできない状態になる．掑食 } \\
\text { 障害がある. 発語が少ない. 歩行時に軽 } \\
\text { 度のふらつきがみられる. }\end{array}$ \\
\hline 3. 普通 & $\begin{array}{l}\text { 日常生活において, 行動に時間を要する } \\
\text { ときもあるが, 歩行状態や上肢の動きに } \\
\text { は特に問題ない. }\end{array}$ \\
\hline 4. やや良い & $\begin{array}{l}\text { 歩行や上肢の動きに問題はない. 日中の } \\
\text { 居眠りはなく，発語もスムーズである. }\end{array}$ \\
\hline 5. 良い & $\begin{array}{l}\text { 四肢の動きはスムーズで, 発語にも支障 } \\
\text { がない. 日中は居眠することなく, 蕜下 } \\
\text { ·掑食にも問題ない. }\end{array}$ \\
\hline
\end{tabular}

主に日中の記録である. 活動できる時間帯における行動を評価 するものとする．
品の有効性や, 患者の自宅における生活のパター ンなどを知る手掛かりとなり，診断だけでなく， 栄養・服薬などの各種指導にも活用される。こう した記録は，介護にあたる家族にとっても患者の 状態を客観的にとらえるきっかけとなる。また家 族間の連絡にも活用され，介護者の負担の大きさ が理解されやすいなどのメリットも発生するよう である。

3. 行動を見守る

行動に関係して, 本院で採用している赤外線 システムについても述べておきたい.

院内の機器への影響を避けるため電波は使用せ ず，赤外線によって患者の位置を把握し，ナース ステーションにあるPCのディスプレイ上に表示 する。プライバシーを守りながらの安全確保を目 的としたシステムである。徘䧃の見られる患者に も，できるだけ自由に活動できる範囲を拡大しな がら，居所を随時確認することができる，患者側 の発信機には腕時計タイプと, 招守り袋タイプの 2種がある。これにより「行動を制約される」 「見張られている」との印象を与えず，自発的に 身につけてもらえるようになっている。

\section{安心を与えるケア}

薬骫ではできないケアとして，本院に扔いては 10 年以上にわたり，さまざまなアクティビティ プログラムを企画・実践してきた。

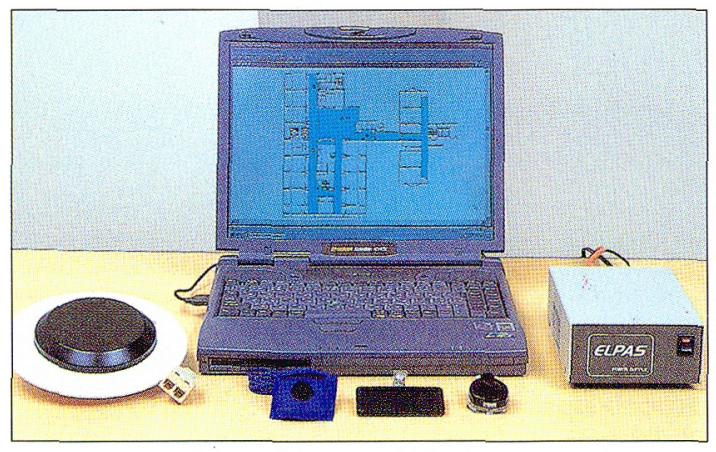

赤外線感知システム 
その中から, 音楽療法・アートセラピー・園芸 療法などを紹介する.

\section{1。この 10 年の取り組み}

本院では 10 年来，患者に対して活性化の試み を積極的に行ってきた。1991年には，当時「リハ ビリ以前のリハビリ」として行っていた『スピー チ療法』やカラオケの活用などに関する報告を， 順天堂医学 37 巻 1 号に揭載している.

1993年にはメーカーとの共同開発により，高 齢者専用カラオケ・レーザーディスクを制作し， 多くの反響を得た。選曲にあたっては，高齢者に 人気の曲を調査した，画面に出る歌詞は文字を大 きくし，さらに歌い出しのタイミングが分かるよ うに，画面に合図が出る，在宅の患者の例では， このカラオケを使い親子で唱歌を歌った後は，本 人も落ち着きを取り戻し，入浴も嫌がらずにでき るようになったとの報告がある，高齢者施設だけ でなく，福祉施設等においても，レクリエーショ ンの一環として導入されている.

1991年当時, 発語を促すために取り入れてい たスピーチ療法は，いわゆる〈言語療法〉ではな い，結婚式のあいさつのように，あるいは出身地 や仕事の話，子供の頃の思い出などを自由に語っ てもらうものである。自分から話し出せない人に はインタビュー形式をとって話を引き出すなど， 気楽に話せる雲囲気を作った，毎朝の回診時の短 い時間だが，人前で話す緊張はほどよい刺激とな るらしく，構音障害の人がスピーチの機会を得た ことにより意欲的になって，発語が改善された例 もあった。

このような取り組みは, 現在の「思い出療法 (後述)」へと継承されている.

2. 水戸黄門方式 $=[$ なじみ $]$

人は自分の得意分野では活力を感じ，意欲を発 揮する。特に痴呆症を含めた高齢者専門病院とい う，無力感を覚えがちな場においては，患者が自 分の力を再発見していく手助けをすることが，大 きな意味をもつ．このため本院には『アクティビ ティチーム』として專任スタッフが設けられてい る. 患者に得意なこと, なじみのあることをやっ

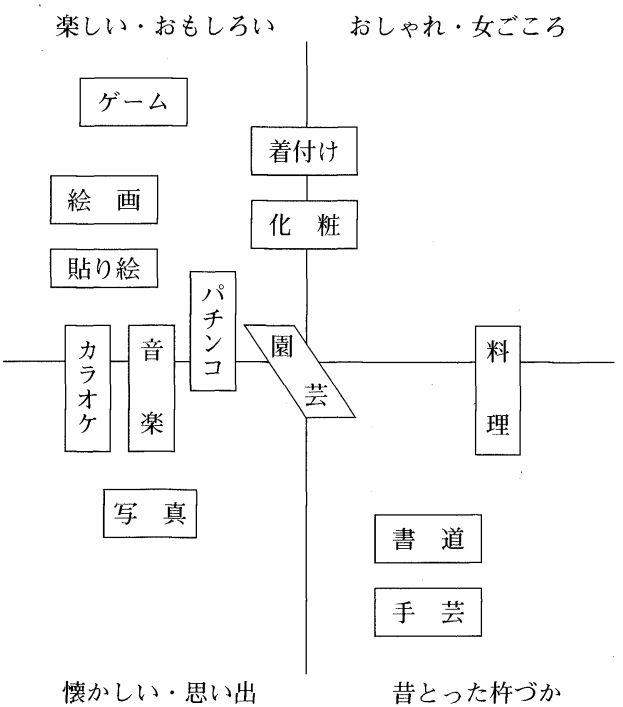

図-5〈楽しみ〉と〈なじみ〉のマトリックス

てもらい, 元気で楽しく過ごしてもらうための仕 掛忛を考え，実践するチームである。

〈レクリエーション〉や〈集団リハビリ〉に違 和感を覚える患者は少なくない，そのため部屋に こもりがちだった人が, 野菜の栽培を始めると, 活動に参加してくれるようになった，風の強い夜 には，倒れていないかと様子を見に車椅子で出て みるほどの熱心さ.やがてスタッフに手入れのコッ や肥料の与え方，草取りなどを職員にアドバイス してくれるほど積極的になった。「昔とった杵づ か」が活かされた好例である。

女性の患者には，化粧や着物を着るプログラム も人気だ。扬気に入りの着物を着ながら，あるい は眺めながら，それにまつわる思い出話などを きっかけに会話がはずみ, 平素は話題に困りがち な職員も，患者とのコミュニケーションを作りや すくなった．痴呆の患者と一緒に料理を作ったこ ともある.邓物を持つことに危惧の声もあったが， フタをあけてみれば，見事な包丁さばきは若い スタッフの比ではなかった．割烹着をつけ仕事を 進めるうちに表情が変化し，母の顔・主婦の顔に なってくる，キュウリをきざむ，ただそれだけの ことが, 痴呆患者の目に輝きと力を取り戻したの 
である。

〈なじみ〉は患者活性化のキーワードだ，本院で は『水戸黄門方式』と呼んでいる。なじみの顔触 れ・なじみの筋書き・なじみの解决による安心感 が人気の時代劇のように, 違和感なく楽しんで受 け入れられるプログラムを，との思いからである (図-5).

\section{3.しらずしらずに}

前掲図にあるようなことを楽しみながら，知ら ずしらずに体を動かし，声を出し，結果的にリハ ビリテーションにもなっていくということが, 高 齢者, 特に痴呆患者には適した方法であると思わ れる. 本人にとっても介護にあたる家族にとって も，頑張りや我慢は好ましいものではない，患者 にとって最も大切な「くつろげる環境」が根底か ら覆されてしまうからである。

介護は, する者も受ける者も共に楽しめる, 余裕 のあるものでなければならない（図-6）。

\section{4. 回想と思い出}

『思い出ミュージアム』の試みは,このような 〈楽しみ〉と〈なじみ〉に重点をおいた，一種の スヌーズレンといえる. 駄菓子屋・貸本屋・足踏み ミシンのある縁側など昭和 30 年代の町並みを再

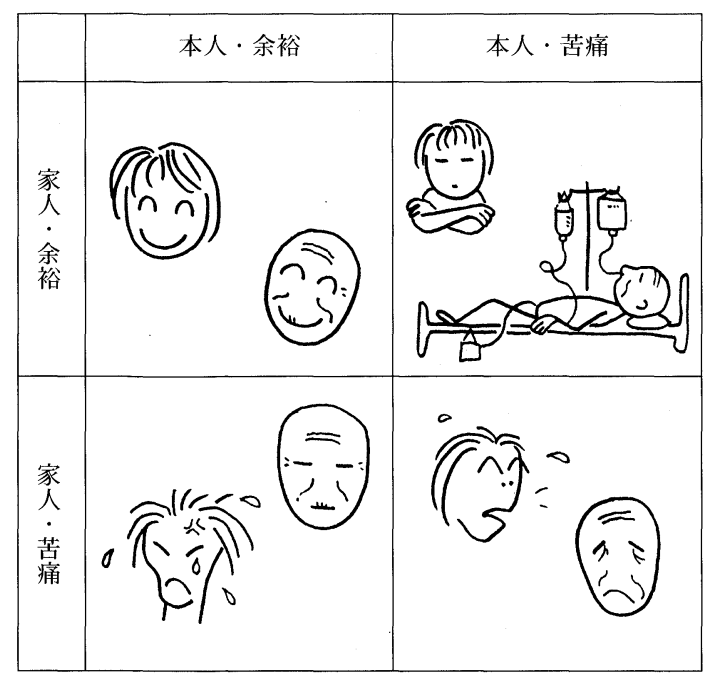

図-6 介護の「ゆとり」
現した空間は, 日本が高度成長にさしかかる頃， 働き盛りであった自分のよき時代を振り返るきっ かけとなる、それだけでなく, 見舞いにきた家族と ともに昔の遊びを思い出したり,時には教えたり, また懐かしい歌を口ずさんだりできる場でもあ る。また屋外にも，同じようなくよき時代〉を思 い出させる空間の屋外版として, 水車小屋や木立 のある庭園を設けた。患者とスタッフが一緒に なって，ここの畑を耕したり，野菜を育てること ができる.

懐かしさの中で宽ぎ，なじみの仲間と作業をし ながら自分の力を改めて認識していくうちに， 「今度は」「次は」という「未来への視線」が産ま れてくる.

高齢者施設に生活している者にとって,こうした 意識を抱くことはなかなか困難なことである．思 い出にひたるだけでなく, 新たな思い出を作って いくという認識の変化, この過程が『思い出療法』 である（困-7）。

『回想療法』では, 懐かしい品物・写真などを手 掛かりとしてコミュニケーションを深めていく手 法がとられることがある。『思い出療法』では, 回想による自己確認・人生の再構築だけでなく, 「今」からさらに一歩を進め「これから」に向かっ ていく視点を持つことになるのである。

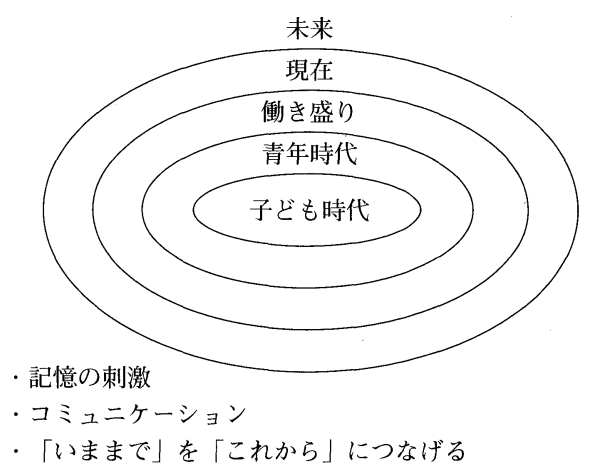

図-7 思い出療法 


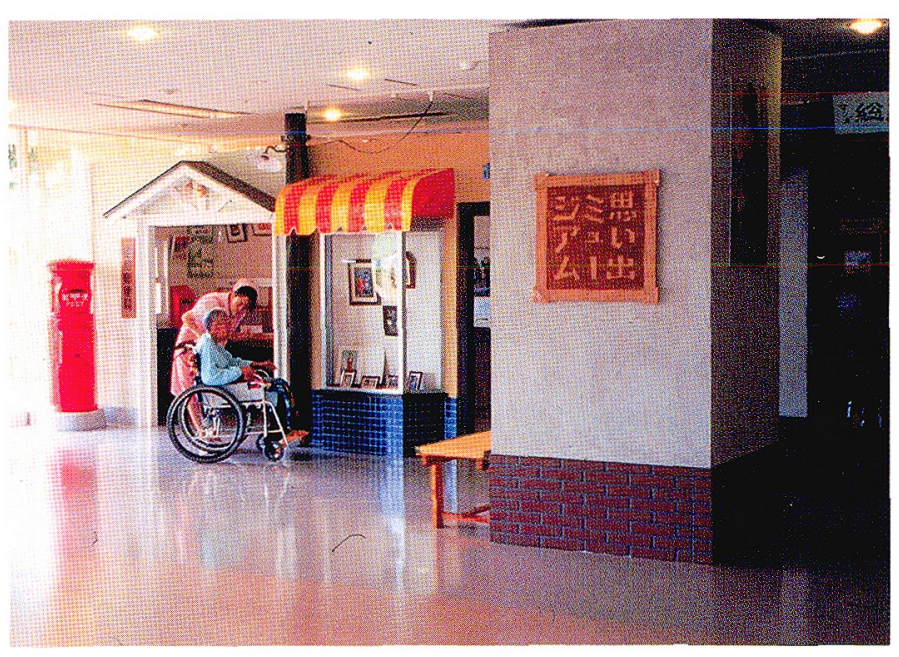

『思い出ミュージアム』室内

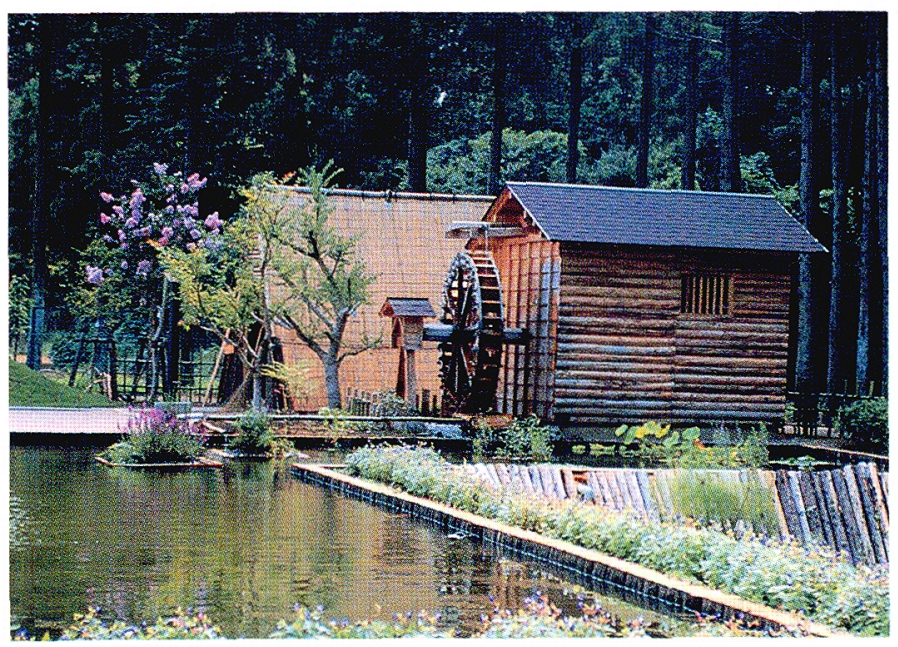

『思い出ミュージアム』屋外

\section{まとめ}

最後に痴朵のケア・介護はどうあるべきかにつ いて，著者が学生時代に指導を受けた室伏君士の 説をあげて扰きたい。彼はメンタルケアの原則と して，以下のようなことを挙げている。

(1)なじみの人間関係をつくること

(2)老人の言動を受容し，理解すること

(3)老人のペースやレベルに合わせること
(4)老人にふさわしい状沉を与えること

(5)理屈による説得よりも，共感的納得を図る (6)上い刺激を少しずつでも絶えず与える (7)孤独に放置しないこと, 寝込ませないこと (8)穴の人に重要なことを簡単にパターン化して， 目の前にしながら，繰り返し教える

(9)老人のよい点を認め，よい付き合いをする

(10)老人の「今」を大切にすること そして, 周囲の環境や処遇の快適，老人の生活 
の満足感や幸福感, 日常生活の活動性の保持と いった, 痴呆老人のQOLの回復・維持・向上に 努めよと述べている。

1.『なじみ』がく場所〉を〈場〉に変える

私自身は, こうした事柄を総括して, 高齢者, 痴呆患者のケアは『なじみ』という概念でとらえ られると考えている。

痴呆患者に何かを行う時, どれくらい『なじみ』 を感じてもらえるかを考える必要がある，なじみ の人と，なじみの場で，なじみのことを行うとい うことが重要だ。それが可能になった時に，患者 にとって施設は単なるく場所〉でなく，心地よい 〈居どころ〉となるのである，施設におけるケア の成否は，そこを物理的な〈場所〉と考えるか 〈場（トポス）〉ととらえるかの違いにかかって くるように思われる.〈場所〉とは, 単にハード ウェアとしての空間および構成物のことである. そこにソフトウェアが加味されることにより，人 としての存在や活動, 感情などを受け入れる, あ るいは包み込む状態になった段階で, 空間として の〈場所〉が，さまざまな可能性をもつく場〉へ と展開していくのである.この〈場作り〉こそ, 痴
呆患者への対応の基本ではないかと考えている. なお，今回発表の場を与えられたことに感謝す るとともに，これまで高齢者ケアを行ってきた 同僚にもあわせて感謝する次第である.

\section{参考文献}

1) Design for Demencia, ( Planning Environment for the elderly and confused ) < by : Margaret P. Calkins, M. Arch $>$ National Helth Publishing, 1988.

2) Weight Loss \& Eating Behiviour in Alzheimer's Patients, (Editor: B. Vellas/S. Rivere/J. Fitten ) Springer Publishing Company, 1998.

3 ) Research and Practice in Alzheimer's Disease, volume2, Springer Publishing Company, 1999.

4 ) 老人性痴呆症のための環境デザイン

一症状緩和と介護をたすける生活空間づくりの指 針と設計一

ユリエル・コーヘン/ジエラルド・D，ワイズマン

著, 岡田威海 監訳/浜崎裕子訳, 彰国社, 1995. 